\title{
Identification of Ice Nucleation-Active Bacteria Isolated from Frost-Damaged Vegetable Leaves
}

\author{
Masao Goto*, Takao Goto** and Tadaoki InABA**
}

\begin{abstract}
Ice nucleation-active bacteria isolated from frost-damaged vegetable leaves in Kagawa Prefecture, Japan were identified as Pseudomonas viridiflava $(80.0 \%$ of total ice nucleation-active bacteria), $P$. syringae $(12.0 \%), P$. fluorescens $(2.7 \%)$, and Erwinia ananas $(5.3 \%)$. The dominance of $P$. viridiflava was remarkably different from the earlier data by Goto et al. in 1988 on the profile of ice nucleation-active bacteria detected in Shizuoka Prefecture on healthy plants such as tea buds, vegetable leaves, and Magnolia denudata flowers. Ice nucleation-active strains of $P$. syringae in this study were different from those in the previous one in biochemical properties such as pyoverdin production, gelatin liquefaction, and acid production from sucrose implying diversity of bacteriological characteristics in the strains of this epiphyte. Saprophytic bacteria not active as ice nuclei were isolated from 64 of 75 broccoli leaves with frost damage, whereas ice nucleation-active bacteria from only 10 similar leaf samples $(13.3 \%)$. On these leaves, ice nucleation-active bacteria comprised 7.6 to $12.6 \%$ of the total population of epiphytic bacteria.
\end{abstract}

(Received February 28, 1989)

Key words: ice nucleation-active bacteria, vegetables, taxonomy.

\section{INTRODUCTION}

Ice nucleation-active bacteria (INA) have been reported to be responsible for frost damage to various plants. Bacteria previously described as INA include Pseudomonas syringae, $P$. fluorescens, $P$. viridiflava, Xanthomonas campestris pv. translucens, a subspecies of $X$. campestris, Erwinia herbicola, E. ananas, and E. uredovora ${ }^{1-5,7-9,11)}$. These INA bacteria have been isolated from plants or plant parts with or without frost injury.

In a previous paper, we reported that the INA bacteria isolated in Shizuoka, Kagawa and Tokushima Prefectures from nonfrost-damaged healthy plants such as various vegetables, tea, and Magnolia denudata included $E$. ananas, a subspecies of $X$. campestris, $P$. syringae and an unidentified pseudomonad ${ }^{3}$. To elucidate the profile of INA bacteria that may directly be involved in frost damage, we have subsequently made a survey of INA bacteria in Kagawa Prefecture from frost-damaged leaves of vegetables and obtained a profile of INA bacteria somewhat different from those on healthy plants in terms of both species diversity and physiological properties of the bacteria isolated.

This paper deals with the results of identification of INA bacteria isolated from frost-damaged leaves of broccoli (Brassica olerasea) and turnip (Brassica campestris).

\section{MATERIALS AND METHODS}

Bacteria. The history of the INA bacteria used in the study is listed in Table 1. Frost-

* Faculty of Agriculture, Shizuoka University, Ohya 836, Shizuoka 422, Japan 静岡大学農学部

** Shikoku National Agricultural Experiment Station, Senyu-cho 1-3-1, Zentsuji, Kagawa 765, Japan 四国農業試験場 
Table 1. History of bacterial strains used in the study

\begin{tabular}{|c|c|c|c|c|}
\hline Code number & No. of strains & Plant & Locality & Date of isolation \\
\hline $\begin{array}{l}8801 \sim 8834, \quad 8836 \sim 8844, \\
8846 \sim 8848, \quad 8859 \sim 8870, \\
8872\end{array}$ & 59 & Broccoli & $\begin{array}{l}\text { Fields of Shikoku Nat. Agr. } \\
\text { Exp. Sta. Kagawa Pref. }\end{array}$ & Feb. 19, 1988 \\
\hline $8901 \sim 8907$ & 7 & Broccoli & Kotohira-cho, Kagawa Pref. & Feb. 4, 1988 \\
\hline $\begin{array}{l}8911 \sim 8913,8915,8917, \\
8919,8922,8923,8926\end{array}$ & 9 & Turnip & $\begin{array}{l}\text { Fields of Shikoku Nat. Agr. } \\
\text { Exp. Sta. Kagawa Pref. }\end{array}$ & Jan. 25,1988 \\
\hline $\begin{array}{l}\mathrm{Pm} 1, \mathrm{Pm} 2 \\
\text { (Pseudomonas syringae pv. }\end{array}$ & mori) ${ }^{2}$ & Mulberry & Kosai-shi, Shizuoka Pref. & Aug. 1973 \\
\hline
\end{tabular}

injured leaves were collected during the day when the morning temperature lowered to -1.4 to $-1.7 \mathrm{C}$. The leaves were immediately cut into $2 \times 2-\mathrm{cm}$ pieces, placed in test-tubes with $10-\mathrm{ml}$ sterilized distilled water, and vigorously shaken on a vortex for several minutes. The washings were spread on nutrient agar plates, and after 4 days separate colonies were picked at random, grown in nutrient broth for 3 days, and screened for their ice nucleation activity at $-10 \mathrm{C}$. The INA bacteria at $-10 \mathrm{C}$ were also active as nuclei in droplet freezing tests at $-3 \mathrm{C}$ with bacterial suspensions prepared from 48 -hr growth on potato-dextrose agar (PDA) slants.

Assay of ice nucleation activity. Ice nucleation activity was determined by droplet freezing method on wax-coated aluminum foil at $-10 \mathrm{C}$. Ten $50 \mu 1$ drops of each nutrient broth culture grown at $25 \mathrm{C}$ for 3 days were placed on aluminum foil floated on cold methanol, and subjected to freezing test. If all drops froze within $30 \mathrm{sec}$, the strains were considered to be the INA bacteria.

Bacteriological properties. Unless otherwise mentioned, all procedures employed for cultural, morphological, physiological and biochemical properties were the same as those described previously ${ }^{2,3}$.

Serological test. An agglutination test was done in test tubes for serological relationship of INA pseudomonads and $P$. syringae pv. mori. Antiserum of $P$. syringae pv. mori (strain S6807), provided by K. Takahashi, National Institute of Sericultural and Entomólogical Science, Tsukuba, Japan, was serially diluted with saline from $1: 40$ to $1: 5,120$, and a $0.5 \mathrm{ml}$ aliquot of each dilution was mixed with the same amount of bacterial suspensions. The tubes were kept at $37 \mathrm{C}$ for $2 \mathrm{hr}$ and then $4 \mathrm{C}$ overnight. Readings were taken after the 24-hr incubation. Two strains of $P$. syringae pv. mori, $\mathrm{Pm} 1$ and $\mathrm{Pm} 2$, were used as the reference strains for the serological test.

Pathogenicity test. Pathogenicity of bacterial strains was determined by inoculating young leaves of field-grown lilac plants (Syringa vulgaris L.) just after sprouting. Isolates were grown for $24 \mathrm{hr}$ on PDA slants and inocula were prepared by suspending the growth in sterile water at the concentration of about $10^{8} \mathrm{cells} / \mathrm{ml}$. Leaves were inoculated by the pin-prick and spray methods. After inoculation, the leaves were covered with plastic bags overnight to ensure high humidity.

\section{RESULTS}

\section{Frequency of ice nucleation-active bacteria}

Frequencies of INA bacteria among total epiphytic bacteria isolated from frost-damaged vegetable leaves are shown in Table 2. The percent of INA bacteria ranged from 0 to $12.6 \%$. No INA bacteria were isolated from pea plants which suffered frost injury. In the fields of Shikoku National Agricultural Experiment Station on February 19, 1988, the epiphytic bacteria were detected on 64 out of 75 broccoli leaves $(85.3 \%$ ). However, INA bacteria were isolated 
Table 2. Frequency of ice nucleation-active bacteria in bacterial population isolated from frostinjured leaves of vegetables

\begin{tabular}{|c|c|c|c|c|c|c|}
\hline Locality & Date & Plant & $\begin{array}{l}\text { No. of leaves } \\
\text { used for } \\
\text { isolation }\end{array}$ & $\begin{array}{l}\text { Total No. } \\
\text { of bacteria } \\
\text { isolated }\end{array}$ & $\begin{array}{l}\text { No. of } \\
\text { INA } \\
\text { strains }\end{array}$ & $\begin{array}{l}\text { INA strains as } \\
\text { proportion of } \\
\text { total strains } \\
\text { (percent) }\end{array}$ \\
\hline $\begin{array}{l}\text { Fields of Shikoku } \\
\text { Nat. Agr. Exp. Sta. }\end{array}$ & Feb. 19, 1988 & Broccoli & 75 & 469 & 59 & 12.6 \\
\hline $\begin{array}{l}\text { Kotohira-cho, } \\
\text { Kagawa Pref. }\end{array}$ & Feb. 4, 1988 & Broccoli & 26 & 80 & 7 & 8.8 \\
\hline $\begin{array}{l}\text { Manno-cho, } \\
\text { Kagawa Pref. }\end{array}$ & Feb. 4, 1988 & Pèa & 12 & 19 & 0 & 0 \\
\hline $\begin{array}{l}\text { Fields of Shikoku } \\
\text { Nat. Agr. Exp. Sta. }\end{array}$ & Jan. 25, 1988 & Turnip & 15 & 119 & 9 & 7.6 \\
\hline
\end{tabular}

from only 10 samples out of $64(13.3 \%)$. The proportion of INA bacteria in the total bacterial population on each leaf varied greatly from 12.5 to $100 \%$ depending on the leaf sample.

\section{Identification of ice nucleation-active bacteria}

Seventy one strains out of $75(94.7 \%)$ belonged to the genus Pseudomonas and only 4 strains $(5.3 \%)$ to the genus Erwinia from their major characteristics. The bacteriological properties of these bacteria are shown in Table 3 .

Among the pseudomonads, 60 strains (group 1) showed the same properties as those of P. viridiflava ${ }^{2,10)}$. Two strains of this group, 8801 and 8869 , were tested for pathogenicity to lilac leaves. Strain 8801 produced small, dark-brown lesions around the wounds produced by pin-prick inoculation. No infection occurred when leaves were spray-inoculated. No symptoms appeared with the strain 8869 either by spray inoculation or by wound inoculation.

Nine pseudomonad strains (group 2) were similar to $P$. syringae in general pattern of bacteriological properties although they differed in some characteristics such as negative responses in pyoverdin production, gelatin liquefaction, and acid production from sucrose. Although the discrepancies in such bacteriological properties made the precise taxonomic affiliation of these strains somewhat difficult, we tentatively identified them with $P$. syringae. Three strains 8846,8860 , and 8865 , were inoculated on young lilac leaves. Strain 8846 produced water-soaked small lesions by wound inoculation, but the other two strains showed no pathogenicity.

Strain 8917 and 8919 (group 3) were different from each other in some properties such as reduction of $\mathrm{NO}_{3}$, hydrolysis of aesculin and Tween 80 , production of urease, and acid production from sucrose. However, these strains were identified with Pseudomonas fluorescens based on their main bacteriological properties.

Four strains (group 4) were entirely identical to Erwinia ananas in their bacteriological properties.

\section{Serological relationship}

None of the INA bacteria used in the study showed agglutination with the antiserum of $P$. syringae pv. mori strain S6807 at the dilution of 1:40. In contrast, two reference strains of $P$. syringae pv. mori, $\mathrm{Pm} 1$ and $\mathrm{Pm} 3$, reacted with the antiserum at the dilution of $1: 320$ and 1:1,280, respectively.

\section{DISCUSSION}

INA bacteria were detected from about 16 percent of vegetable leaves that had suffered frost damage and comprised from 0 to 12.6 percent of the total epiphytic bacteria population depending on the samples. These figures are too low to suggest the importance of INA bacteria as the inducer of frost damage to vegetables. However, the isolation frequency might be- 
Table 3. Comparison of characteristics of ice nucleation-active bacteria isolated from frostinjured vegetable leaves a)

\begin{tabular}{|c|c|c|c|c|c|c|c|c|}
\hline \multirow{2}{*}{ Characteristics } & \multicolumn{4}{|c|}{ Group b) } & \multirow{2}{*}{$P v c)$} & \multirow{2}{*}{ Ps } & \multirow{2}{*}{ Pf } & \multirow{2}{*}{$\mathrm{Ea}$} \\
\hline & 1 & 2 & 3 & 4 & & & & \\
\hline Oxidase & $-d)$ & - & + & - & - & - & + & - \\
\hline Potato rot & + & - & - & - & + & - & & $(-)$ \\
\hline Arginine dihydrolase & - & - & + & - & - & - & + & $(-)$ \\
\hline Tobacco hypersensitivity & + & + & - & - & + & + & & $(-)$ \\
\hline Reduction of $\mathrm{NO}_{3}$ & - & - & $\mathrm{v}$ & - & - & - & & - \\
\hline$\alpha$-ketogluconate production & - & - & + & - & - & $(-)$ & & - \\
\hline Hydrolysis of: gelatin & + & - & + & + & + & $\mathbf{v}(+)$ & + & + \\
\hline aesculin & + & + & $\mathrm{v}$ & + & $(+)$ & $(+)$ & & $\mathrm{v}$ \\
\hline casein & + & + & + & - & $(+)$ & $(+)$ & & $(+)$ \\
\hline Tween 80 & - & - & $\mathbf{v}$ & - & - & $\mathrm{v}(+)$ & $\mathrm{v}$ & $\mathrm{v}$ \\
\hline starch &,$+ \mathrm{w}$ &,$+ \mathrm{w}$ & - & - & $-(+, w)$ & $(+)$ & - & $+(-)$ \\
\hline Levan formation & - & - & - & - & - & $\mathrm{v}(-)$ & - & $(-)$ \\
\hline Production of tyrosinase &,$+ w$ &,$+ \mathrm{w}$ & - & - & & $(\mathrm{v})$ & & $(-)$ \\
\hline Urease & - & - & $\mathrm{v}$ & - & $(-)$ & $(+)$ & & - \\
\hline Phosphatase & + & + & - & - & $(-)$ & (v) & & \\
\hline $\mathrm{O}-\mathrm{F}$ test & $\mathrm{O}$ & $\mathrm{O}$ & $\mathrm{O}$ & $\mathrm{F}$ & $\mathrm{O}$ & $\mathrm{O}$ & $\mathrm{O}$ & $\mathrm{F}$ \\
\hline Fluorescent pigment & + & - & + & - & + & + & + & - \\
\hline Yellow pigment & - & - & - & + & - & - & - & + \\
\hline Flagellation & Po & Po & Po & $\mathrm{Pe}$ & Po & Po & Po & $\mathrm{Pe}$ \\
\hline Lecithinase & - & - & + & + & - & $\mathrm{v}(-)$ & $\mathrm{v}$ & $(-)$ \\
\hline Red. subst. from sucrose & + & + & + & - & $(-)$ & $(+)$ & & $+(v)$ \\
\hline Production of: acetoin & - & - & - & + & $(-)$ & $(-)$ & & + \\
\hline indole & - & - & - & + & $(-)$ & $(-)$ & & $+(\mathrm{v})$ \\
\hline $\mathrm{H}_{2} \mathrm{~S}$ & - & - & + & + & $(-)$ & $(-)$ & & $\mathrm{v}(+)$ \\
\hline Pectate liquefaction & + & - & - & - & $(+)$ & (v) & & - \\
\hline Split of protocatechuate & + & + & + & - & & + & + & \\
\hline Use of: D-arabinose & - & - & - & + & & $(\mathrm{v})$ & - & \\
\hline sucrose & - & - & $\mathrm{v}$ & + & $\mathrm{v}(-)$ & $\mathbf{v}(+)$ & $\mathbf{v}$ & $(+)$ \\
\hline cellobiose & - & - & - & + & $(+)$ & $(+)$ & - & + \\
\hline trehalose & - & - & + & + & - & $(-)$ & $\mathbf{v}$ & + \\
\hline raffinose & - & - & - & + & - & $\mathrm{v}(-)$ & & $+(\mathrm{v})$ \\
\hline erythritol & + & + & + & - & + & $\mathrm{v}(+)$ & $\mathrm{v}$ & $(-)$ \\
\hline tryptophan & - & - & + & - & & - & $\mathrm{v}$ & \\
\hline varelate & + & + & + & - & & $\mathrm{v}$ & $\mathbf{v}$ & \\
\hline malonate & + & - & + & - & $(+)$ & $\mathbf{v}(+)$ & $\mathrm{v}$ & $-(+)$ \\
\hline Pathogenicity to lilac & $\mathrm{v}$ & $\mathrm{v}$ & & & & & & \\
\hline
\end{tabular}

a) All strains tested were positive in use of xylose, galactose, melibiose, glycerol, inositol, sorbitol, histidine, ascorbate, caprate, caproate, gluconate, lactate, propionate, ketoglutarate, L-tartrate, Dtartrate, and fumarate.

All strains tested were negative in methyl red test, denitrification, hydrolysis of cotton seed oil, production of urease and phenylalanine deaminase, accumulation of poly- $\beta$-hydroxybutyrate, growth in $5 \% \mathrm{NaCl}$ broth, use of melezitose, glycogen, dulcitol, and agglutination reaction to antiserum against Pseudomonas syringae pv. mori, strain S6807.

b) Strains of group 1: $8801 \sim 8834,8836 \sim 8844,8847,8848,8859,8861,8862,8864,8869,8870,8872$, $8902 \sim 8907,8923,8926$ (60 strains: $80 \%$ )

Strains of group 2: $8846,8860,8863,8865 \sim 8868,8901,8922(9$ strains: $12 \%)$

Strains of group 3: 8917,8919 (2 strains: $2.7 \%$ )

Strains of group 4: 8911 8913, 8915 (4 strains: $5.3 \%$ )

c) Pv-Pseudomonas viridiflava, Ps- $P$. syringae pathovars, Pf-P. fluorescens (biovar V), and Ea-Erwinia ananas, respectively. Data were taken from Bergey's Manual of Systematic Bacteriology Vol. 1 (1984). Data of $P$. viridiflava, $P$. syringae and $E$. ananas in $(\quad)$ were taken from Goto and Matsumoto ${ }^{2)}$ and Goto et al. ${ }^{3)}$, respectively.

d) $+: 80 \%$ or more of strains positive; $-: 80 \%$ or more strains negative; v: varied by strains; w: weak reaction; O: oxidative; $\mathrm{F}$ : fermentative; Po: polar; Pe: peritrichous. 
come greater if selective media are employed, because the presence of other epiphytic bacteria often make the detection of INA bacteria at low populations very difficult. Therefore, the present data do not necessarily imply that these INA bacteria are of minor importance as the inducer of frost damage.

We have reported in a previous paper ${ }^{3)}$ that Pseudomonas syringae was the major INA bacterium on the healthy vegetable leaves. Wen et al. ${ }^{12}$ also found that the profile of INA bacteria surveyed on Chinese cabbage without frost damage in China comprised mainly of $P$. syringae ( 93 percent of total INA bacteria isolated). The results obtained in the present study indicate, however, that the population of INA bacteria on vegetable leaves with frost damage consisted mainly of $P$. viridiflava; other bacteria such as $P$. syringae, $P$. fluorescens, and Erwinia ananas were rather minor components. The pending questions are if the dominance of $P$. viridiflava depends on the locality where the cruciferous plants grown, or on the direct or indirect effects of frost damage on the epiphytic profile of INA bacteria.

$P$. viridiflava causes soft rot of various vegetables, especially of cabbage and broccoli under cool weather conditions. In winter through early spring, frost-injuries induced by $P$. viridiflava may stimulate soft rot development by producing new infection sites. A strain of $P$. viridiflava used for pathogenicity test produced small, dark brown lesions around puncture wounds made on young lilac leaves. However, no further enlargement of these lesions was observed indicating that virulence was weak. Because other strains produced no symtoms, strains of $P$. viridiflava seem to vary in this trait although they were consistent in the capacy to rot potato slices.

Nine strains of group 2 identified as $\boldsymbol{P}$. syringae were different from those detected from healthy vegetable leaves and Magnolia denudata flowers in some physiological and biochemical properties such as pyoverdin production, gelatin liquefaction, and acid production from sucrose $^{3}$. $P$. viridiflava and $P$. syringae pathovars are similar in their phenotypic traits with a limited number of differential characteristics such as potato rot, use of sucrose, D-tartrate, and $\alpha$-ketoglutarate. The present strains of group 2 showed intermediate properties of these two bacteria suggesting necessity of reinvestigation of their taxonomic relatedness. Although one strain, 8846, showed weak virulence on young lilac leaves, no pathogenicity was revealed by other strains tested. Virulence of the pathogenic strain was equivalent to that of $P$. syringae strains in our previous paper ${ }^{3)}$. These facts imply that the epiphytic strains of $P$. syringae seem to have the considerable diversity either in bacteriological as well as pathological traits.

Two strains of INA pseudomonads (group 3) were identified as $\boldsymbol{P}$. fluorescens on the basis of bacteriological properties such as positive reactions in oxidase, arginine dihydrolase and production of pyoverdin. Although strain 8917 different from strain 8919 in some phenotypic traits, their general patterns of bacteriological properties were in agreement with those of biovar $\mathrm{V}$ of the bacterium, because this biovar consists of diverse strains in bacteriological properties ${ }^{10}$. Although INA strains of $P$. fluorescens have been repeatedly isolated from soybeans and kidney beans ${ }^{4}$, its distribution on cruciferous plants seems not to be very high. Wen et al. ${ }^{12}$ also indicated that the isolation frequency of INA strains of $P$. fluorescens from Chinese cabbage was only $4.2 \%$.

Four strains of INA Erwinia were identical in their bacteriological properties with E. ananas ${ }^{3,6}$. There was no strains identical to E. uredovora and E. herbicola both of which have been reported as INA erwinias ${ }^{8,9)}$. As far as winter vegetables are concerned, erwinias seem to be the minor component of INA epiphytes on cruciferous plants.

We thank K. Takahashi for the antiserum of Pseudomonas syringae pv. mori, strain S6807 and C. Morris for critical reading of the manuscript.

\section{Literature cited}

1. Azad, G. and Schaad, N.W. (1988). Phytopathology 78: 95-100. 
2. Goto, M. and Matsumoto, K. (1986). Ann. Phytopath. Soc. Japan 52: 69-77.

3. Goto, M., Huang, B.-L., Makino, T., Goto, T. and Inaba, T. (1988). Ibid. 54: 189-197.

4. Kaneda, T. (1986). Appl. Environ. Microbiol. 52: 173-178.

5. Kim, H.K., Orser, C., Lindow, S.E. and Sands, D.C. (1987). Plant Disease 71: 994-997.

6. Lelliott, R.A. and Dickey, R.S. (1984). In Bergey's Manual of Systematic Bacteriology. Vol. 1. (Krieg, N.R. and Holt, J.G. eds.). The Williams \& Wilkins Co., Baltimore. pp. 409-476.

7. Lindow, S.E. (1982). In Phytopathogenic Prokaryotes. Vol. 1 (Mount, M.S. and Lacy, G.H. eds.). Academic Press, New York. pp. 335-362.

8. Lindow, S.E., Arny, D.C. and Upper, C.D. (1982). Phytopathology 68: 523-527.

9. Newton, D. and Hayward, A.C. (1986). Australian Plant Path. 15: 71-73.

10. Palleroni, N.J. (1984). In Bergey's Manual of Systematic Bacteriology. Vol. 1. (Krieg, N.R. and Holt, J.G. eds.). The Williams \& Wilkins Co., Baltimore. pp. 141-199.

11. Paulin, J.-P. and Luisetti, J. (1978). Proc. 4th Int. Conf. Plant Path. Bact. Vol. II. Angers. pp. 725731.

12. Wen, A.-M., Morris, C., Zhu, J.-K., Xu, X.-H. and Di, Y.-B. (1989). Appl. Environ. Microbiol. (in press).

\section{和 文 摘 要}

\section{後藤正夫・後藤孝雄・稲葉忠興 : 凍霜害の被害を受けた野菜葉から分離した氷核活性細菌の同定}

1988 年 1 月特よび 2 月に香川県で涷霜害の被害を受けたブロッコリー, カブおよびェンドウの葉から氷核 活性細菌の分離を行い, 前 2 者から 75 菌株を得た。このうち 60 菌株 (80\%) が Pseudomonas viridiflava, 9 菌株 (12.0\%) が P. syringae, 2 菌株 (2.7\%) が P. fluorescens, 4 菌株 (5.3\%) が Erwinia ananas と同定さ れ，P. viridiflava の比率が高い点が注目された。P. syringae の 9 菌株は健全野菜葉から分離した氷核活性 $P$. syringae と 2, 3 の性質で異なった。P. viridiflava 和よび P. syringaeの一部の菌株にはライラックの若葉 に弱い病原性を示すものがみられた。P. fluorescens の性質は biovar V のそれに類似した。凍霜害の被害を 受けたブロッコリーの葉では，調査した 75 葉中，64 葉（85.3\%）から表生細菌が分離され，このなかで 10 葉 $(13.3 \%)$ から氷核活性菌が分離された。表生細菌に占める水核活性細菌の割合は, 採集地点, 植物の種 類によって 7.6〜12.6\% であったが，個々の被害葉についてみると0〜100\% と大きな変異がみられた。 